\title{
Local knowledge of Karangwangi People of Cianjur District, West Java, Indonesia on water pollution of the Cikawung River
}

\author{
DINI PRIMADIANI ${ }^{1}$, JOHAN ISKANDAR $^{2, \boldsymbol{\varphi}}$, SUNARDI $^{2}$ \\ ${ }^{1}$ Environmental Study Master Program, Universitas Padjadjaran. Jatinangor, Sumedang 45363, West Java, Indonesia \\ ${ }^{2}$ Department of Biology, Faculty of Mathematics and Natural Sciences; and Postgraduate of Environmental Science (PSMIL \& DIL) and Institute of \\ Ecology (PPSDAL), Universitas Padjadjaran. Jl. Raya Bandung-Sumedang Km21, Jatinangor, Sumedang 45363, West Java, Indonesia. \\ Tel: +62-22-77912. `email: johan.iskandar@unpad.ac.id
}

Manuscript received: 11 November 2017. Revision accepted: 10 April 2018.

\begin{abstract}
Primadiani D, Iskandar J, Sunardi. 2018. Local knowledge of Karangwangi People of Cianjur District, West Java, Indonesia on water pollution of the Cikawung River. Asian J Ethnobiol 1: 9-14. In the past, village people of Karangwangi, Cianjur District, West Java Province did not face any water supply problem, including supply from the Cikawung River. Of late, however, they are experiencing problems with water sources, particularly water supply from the Cikawung River. Since pesticides have been intensively used in the local agroecosystems, such as irrigated rice fields and monoculture vegetable gardens, the Cikawung river water is polluted. In addition, the consequences of an increase in the conversion of forests and traditional mixed-gardens into agricultural and settlement areas have dramatically affected hydrological balances. On this background, this research was carried out to elucidate the local knowledge of the Karangwangi people on the status of pollution of water of the Cikwaung river. This research used a mix of qualitative and quantitative methods with descriptive qualitative analysis. The qualitative data collection technique used was in-depth interviews with informants chosen purposely with snowball sampling. The quantitative data collection technique was interviews with respondents using questionnaires and measurement of physical, chemical and biology parameters of Cikawung River water. Results of this research confirm that village people of Karangwangi have considerable local knowledge on water categorization, pollution, and pollution indicators of the Cikawung River
\end{abstract}

Keywords: Local Knowledge, Cikawung River, Karangwangi Village, Pesticides, Water Pollution

\section{INTRODUCTION}

In the past, most village people of Java, including those of West Java, were getting an appropriate supply of water from various sources, such as wells, springs, showers, and rivers. The water supply was adequate and proper because the village environment was adequately maintained, and the population was limited. The village people used water based on the local knowledge and cosmos or beliefs (cf. Iskandar 2012). The term local knowledge, in this case, is synonymous with various terms, including rural people's ability, indigenous technical knowledge, insider knowledge, traditional environmental knowledge, peoples' science, and folk knowledge. It may relate to any knowledge held more or less collectively by a population, informing understanding of the world, embedded in and conditioned by local tradition (Sillitoe 2002). The village people's knowledge of water ranges from their ability to categorize water to maintain water resources based on the traditional conservation practices. Some water resource areas, such as upstream forests and springs, have been considered sacred places and prohibited from disturbances.

Both local knowledge and cosmos or belief systems have played essential roles in utilizing and maintaining the water resources in the village ecosystem. Such local knowledge of village people is inherited from their ancestors and transmitted orally from generation to generation through the mother language. In addition, local knowledge has been obtained by trial and error of the village people during their interaction with the local environment for a long time (Iskandar 2009). Indeed, a long process of interaction between the village people and their environment has resulted in the local wisdom of the village about the climate (cf. Aulia and Arya 2010).

However, due to human population increase, intensive penetration of market economy to village areas, and rapid development of new technologies, some local knowledge of the village people has eroded. As a result, the environment and natural resources, including water, have not been widely exploited. Moreover, some environmental destruction has not been avoided (Iskandar 2014). Unlike in the past, water availability has been changed due to the destruction of the watershed area. Therefore, there has been a water shortage during the dry season in many villages. Conversely, during the wet season, there has been flooding. The water supply is very high in the wet season, but its quality is terrible because it predominantly contains high sediment content. It has been caused due to the destruction of watersheds. For example, the forests and traditional agroforestry systems have been converted to other land uses, such as settlements and other human facilities. Consequently, rainwater rarely penetrates deep soil during the rainy season but directly flows into the river and causes flooding. Conversely, there is a lack of water supply during the dry season due to minimal water stock in the deep soil. In addition, the quality of water in the river 
has decreased due to many factors, including pollution from pesticides. This is because many pesticides have been intensively used in the wet rice fields and commercial gardens, the leaching of which come into the rivers. As a result, the water resources in many villages are no longer sufficient, and water has become an economically highvalue commodity (cf. Susilo et al. 2016).

In general, the availability of water supply in the village ecosystem is dependent on the condition of the watershed environment. Therefore, any change in the watershed environment may change the water supply of the rivers (cf. Wahid 2009; Halim 2014; Sri et al. 2014). The lowland and riverbank are known as fertile soil due to sediment carried along by the river, and this area is predominantly used for agricultural purposes (cf. Rochgiyanti 2011). In many cases, some conflicts between conservation, agriculture, and settlement areas have occurred caused by socioeconomic changes of the community. Moreover, they have changed human behavior about the environment (cf. Hakim et al. 2016).

The Cikawung river of Karangwangi village, Cianjur District, West Java, has a vital role for village people. For example, it has been used to irrigate the wet rice, wash, and take baths by village people. However, due to intensive use of pesticides in the wet rice field and commercial gardens, this river has been polluted, and its water organisms have been killed (cf. Collins 1975) cited by Tilak et al. (2007). In addition, the intensive use of synthetic pesticides has caused erosion of local knowledge about biopesticides (Iskandar 2014).

This paper aims to elucidate the local knowledge of the Karangwangi village on the water pollution of the Cikawung River. Three different aspects are studied in this paper: local understanding of village people of Karangwangi on river water, water pollution, and indicators of water pollution using macro-zoobenthos diversity.

\section{MATERIALS AND METHODS}

\section{Location}

This research was conducted from February to May 2017 in Karangwangi Village, Cianjur District, West Java. The Karangwangi Village is located directly adjacent to the Indonesian Ocean on the South. This village is situated approximately 200-275 m above sea level. Karangwangi Village has about 2,300 hectares, consisting of 1,115 hectares of rice fields and gardens. Jayanti Nature Reserve also borders Karangwangi Village. Cikawung River is one of the rivers that pass Karangwangi Village.
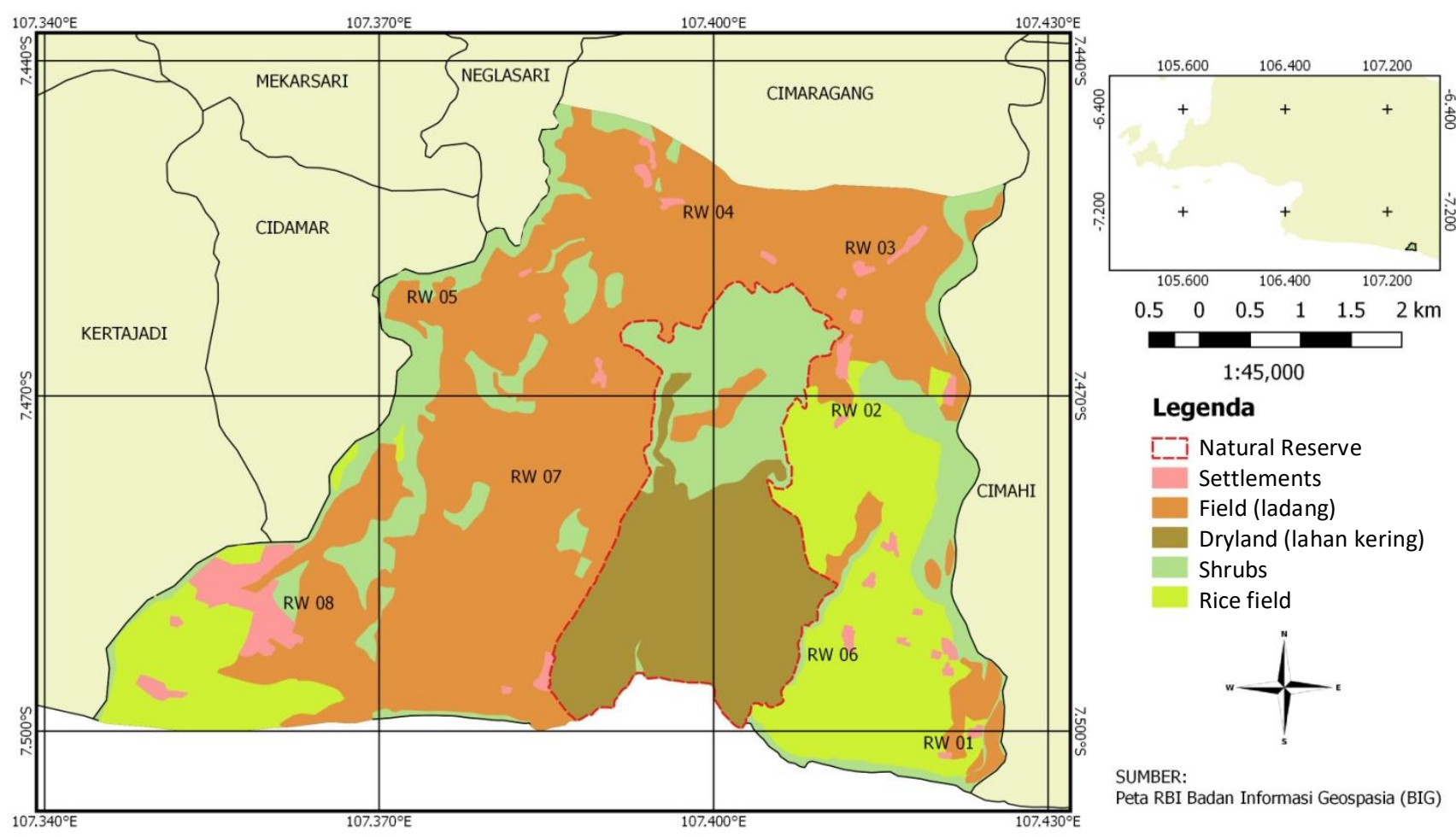

Figure 1. Research location in Cikawung River, Karangwangi Village, Cianjur Subdistrict, West Java, Indonesia 


\section{Data collection}

Qualitative and quantitative mixed-method with ethnoecology and ethnobiological approach was applied for data collection (Iskandar 2012; Alburque et al. 2014). Several field research techniques such as observations, indepth interviews, semi-structured interviews, and biological samplings were undertaken to collect the primary data in the field. The observation was carried out to record the general condition of the Cikawung River, agroecosystem types, and settlement environment. The Deep interview was applied to understand the village people's knowledge of the Cikawung river of Karangwangi. It was carried out with informants, such as informal leaders, the village staff, farmers, fishers, etc. The structured interview was undertaken with randomly selected respondents. The total number of respondents was calculated by the Lynch formula (Lynch et al. 1974).

$$
\mathrm{n}=\frac{N \cdot Z^{2} \cdot p(1-p)}{N \cdot d^{2}+Z^{2} \cdot p(1-p)}
$$

\section{Where:}

$\mathrm{n} \quad=$ sample number (respondents)

$\mathrm{N}=$ population number

$\mathrm{Z}$ = normal variable value for level of confidence 95\% (1.96)

$\mathrm{P} \quad=$ highest proportion $(0.5)$

$\mathrm{D}=$ sampling error (0.10) (Lynch 1974).

Based on the statistical formula, it has been determined that the total number of household respondents is 92. Each of them was interviewed using the questionnaire. In addition, biological sampling was also carried out by collecting water samples of the Cikawung River, and some variables, including $\mathrm{COD}, \mathrm{BOD}, \mathrm{PH}$, and macrozoobenthos diversity, were analyzed in the laboratory.

\section{Data analysis}

The qualitative data was analyzed through several stages (Iskandar 2012). Firstly, data obtained by observation and in-depth interviews were cross-checked. Secondly, the data were summarized and synthesized. The quantitative data obtained by the questionnaire were analyzed by simple statistical methods like calculating the percentage of respondents answering the questionnaires, as shown below:

$$
\mathrm{P}=\frac{f}{N} \times 100 \%
$$

Where:

$\mathrm{P} \quad=$ Percentage of the total

$\mathrm{f} \quad=$ Data Frequency

$\mathrm{N}=$ Total number of processed samples (Warsito, 1992).

The data of macro-zoobenthos diversity was analyzed using Shanon-Wiener Diversity Index (Odum 1981; Yuliana et al. 2012).
Shanon-Wiener Diversity Index $\left(\mathrm{H}^{\prime}\right)=-\sum(\mathrm{ni} / \mathrm{N}) \ln (\mathrm{ni} / \mathrm{N})$

Where:

$\mathrm{ni} \quad=$ number of individual genus $-\mathrm{i}$

$\mathrm{N}=$ total number individual all species

$\ln =$ number of species

\section{RESULTS AND DISCUSSION}

\section{The water of the Cikawung river}

In general, all informants of village Karangwangi village opined that the quantity and quality of water in the Cikawung River has changed. The amount of water in the Cikawung River was more stable in the past. Even during the dry seasons, the water of Cikawung never decreased too much. Nowadays, however, during the dry season, particularly during the drought periods caused by the climatic anomaly, the water level in the river of Cikawung decreases drastically. As a result, many people of Karangwangi village face problems obtaining sufficient water for their daily needs, such as washing and taking a bath.

According to some informants, the water shortage has been caused by many factors, both natural and manufactured or anthropogenic - the main natural factors long-dry seasons caused by the climatic anomaly. In addition, different anthropogenic factors are predominant causes for the decrease of water in the Cikawung River and other water sources. On the one hand, the water demand has increased due to population increase, and water in the various water resources has been intensively exploited; on the other hand's water supply has decreased due to the destruction of vegetation of the watershed, and the forests and traditional agroforestry systems have been converted to settlements and agricultural areas. The lack of water in the Cikawung River, particularly during the dry season, has affected the village people of Karangwangi village. Cikawung River was traditionally used for taking baths and washing. In addition, it was predominantly used for agricultural purposes, such as irrigation of the rice fields and monoculture gardens. Based on the monoculture garden, some farmers of the Karangwangi village have been intensively cultivating chili crops for two years. Since chili production has been high, some people are interested in planting chili pepper.

About the environmental history, in the past, the Karangwangi people cultivated rice both in the wet-rice field (sawah) and the swidden farming system (huma or ladang) (cf. Iskandar and Budiawati 2011). They grew rice based on the local knowledge, cosmos, and applied LEISA (Low external inputs and Sustainable Agriculture) system (cf. Reijntjes et al. 1992). For example, various inputs such as rice seeds, organic fertilizer, and biopesticides were obtained from the village. Moreover, the Cikawung River was less polluted. Nowadays, the practice of swidden cultivation by farmers has decreased. In addition, the cultivation of rice in sawah and planting commercial crops, such as chili pepper in the gardens, has intensified the use of chemical fertilizers and pesticides. As a result, the 
Cikawung River has been polluted by pesticides. The farmers have adopted the changes in rice and chili pepper cultivation to increase population density and intensive penetration of the market economy to villages. The hydrological system of the Cikwung river has changed due to disturbances in the vegetation of forests and mixedgardens in the watershed. Therefore, according to some informants, for rehabilitation of the Cikawung watershed, some plant species, including Picung (Pangium edule) and Kiara (Filicium decipiens), have been planted in areas of $100 \mathrm{~m}$ from upstream area. This program has not been optimally undertaken due to a lack of human resources. According to informants, some species, such as changkring (Erythrina fusca), kiray (Metroxylon sagu), Benda or teureup (Artocarpus elastica), and Ficus racemosa, have been considered for planting in the riverbank area. These plants can be appropriately grown in the lowland area (Ulfah et al., 2015). Two plant species, namely Ficus racemosa and Artocarpus elastica, of the Moraceae family have predominantly been grown in particular areas close to water sources. In general, plants of the Moraceae family have the ability of hydrological conductance, which can absorb water in large quantities at night. That is because the plants of the Moraceae family have a deep root system (Sofiah and Fiqa 2014).

\section{Water Pollution of Cikawung River}

Based on the results of in-depth interviews with informants, it can be inferred that the quality of water of the Cikawung River has also decreased. According to the perception of 92 respondents, the water of the Cikawung River can be divided into two categories, namely dirty water and clean water. The dirty water is polluted by waste and has become turbid and developed bad smells (Table 1).

As mentioned by informants, the water of the Cikawung river has become turbid due to cileucang (runoff) containing a lot of mud or sediment. That is why the people of village Karangwangi have traditionally used the water of the Cikawung river for bathing and washing only. Water for cooking and drinking has been predominantly obtained from wells and rainwater harvesting collected and stored in gallons. Unlike the wet season, in the dry season, the water of the Cikawung River becomes clear. Therefore, during the dry season, the people of Karangwangi have used water of the Cikawung River for drinking, cooking, washing, and bathing.

Table 1. Category of polluted water based on the respondents' perception

\begin{tabular}{lcc}
\hline $\begin{array}{l}\text { Indicator of } \\
\text { polluted water }\end{array}$ & $\begin{array}{c}\text { Number of } \\
\text { respondents }\end{array}$ & $\begin{array}{c}\text { Percentage of } \\
\text { respondents }\end{array}$ \\
\hline Color & 82 & 89.13 \\
Waste & 20 & 21.73 \\
Smell & 36 & 39.13 \\
Taste & 8 & 8.69 \\
\hline
\end{tabular}

Unlike the Karangwangi people, the water of the Cikawung river is categorized by urban people of Jakarta based on sources (the local water company/PAM, private drink, washing, latrine/MCK; river, rainwater), color (colored including chocolate and black and colorless), smell (odorless and smell including the smell of soil, rust, stench), motion (flowing profusely/flooding, regular, and not flowing), use (drinking and cooking, bathing and washing, not suitable for anything), and how to obtain (without cost and labor, and vice versa) (Ahimsa-Putra 1997).

According to informants, the deteriorating quality of water of the Cikawung River is also indicated by changes in the diversity of fish. A wide variety of fish has been recorded in the Cikawung river due to support by good quality of water. Today, however, the population of fish species, such as eel or belut (Monopterus albus), catfish (Clarias sp.), lubang (Anguilla marmorata), and beunteur (Puntius binotatus), has decreased. It has been estimated that about $30 \%$ of the fish population has decreased compared to 40 years ago. The decrease in fish population has been caused mainly by the intensive use of synthetic pesticides. Synthetic pesticides are chemical materials that can poison fishes because fishes are good accumulators of several kinds of pesticides, especially lipophilic pesticides (pesticide which easily attaches to fat tissues) (Taufik 2011).

In addition to pesticides of agricultural origin, the river Cikawung has also been polluted by pesticides used by people to catch fish. In the past, village people of Karangwangi used to catch fish by fishing nets (heurap) or natural poisons made of plants roots. Presently, some people use chemical pesticides to catch fish and enhance the size of fish catches.

Supriyono et al. (2015) explained that synthetic pesticides are toxic chemical materials that can disturb ecosystem balance and disturb aquatic organisms. Catching fish using synthetic pesticides for a particular purpose needs selective permission to minimize its negative impact on the ecosystem. The kinds of pesticides used by farmers in the study area are starban, aripo, puradan, TSP, Culakron, etc.

Traditionally, the villagers of Karangwangi knew various plants that could be used as natural pesticides to kill pests. For example, fruits of Picung (Pangium edule) have been popularly used as an herbal pesticide by rural people. The preparation method involves dissolving pounded fruits in water which is then sprayed on pests. Picung can be used to kill insect pests, such as walang sangit (Leptocorisa acuta). Most village people were also aware that coconut (Cocos nucifera) mixed with cassava (Manihot esculenta) could be used as a natural agent for poisoning wild boar (Sus scrofa). Nowadays, however, natural pesticides are not used longer by villagers. It is because people assume that synthetic pesticides can kill pests more effectively and faster when compared to natural pesticides. In addition, various synthetic pesticides are readily available in markets, whereas the plants used as herbal pesticides are rarely found in the ecosystem. As a result, the natural pesticides are less predominantly used by 
farmers, and later on, they will be abandoned entirely or forgotten (Kardinan 2011).

Pesticides can cause a negative impact on the environment and the people who are directly or indirectly exposed to them. Pesticides that have been sprayed can get into the human body through skin absorption (Chaturverdi et al., 2013). Informants of this study also explain that presently several people in Karangwangi have experienced skin diseases; one such person lives in Situwangi. This fact also indicates that pesticides have polluted the water of the Cikawung River. However, this has not influenced the villagers to stop using synthetic pesticides.

As presented in Table 1, people of the Karangwangi village categorize the polluted water of the Cikawung river not only based on change of color but also by rotten smell developing due to contamination. Informants explain that although the water smelled and contained waste, the people in Karangwangi still used it as long as the water did not smell soap or pesticides. If river water doesn't smell, people can still use it for wash and bath.

The results of the semi-structured interview indicated that $35 \%$ of respondents mentioned that the Cikawung River at Garedog area has a high level of pollution, $24 \%$ of respondents said that the Geredog area has a moderate level of pollution, and $37 \%$ of respondents mentioned that the Situwangi area has the lowest level of pollution. The area is located upstream and is expected to have a high level of pollution because this area is close to the wet rice fields where the use of pesticides is intensive. On the contrary, the Situwangi location is expected to have the lowest pollution level because the discharge of water is higher when compared to the other areas. In other words, the pollution level in the Cikawung River is expected to decrease in the downstream area due to water dilution, caused by increasing water volume due to discharge from the creeks originating from the forests of the nature reserve Jayanti.

\section{Macro-zoobenthos diversity}

Analysis of the macro-zoobenthos diversity in different river locations shows that Situwangi, located downstream, has relatively lower diversity than that of the Geredog and Nempel areas located in the upper stream (Table 2).

It may be assumed that the lower index of a diversity of macro-zoobenthos in the Situwangi area is caused by high water pollution. This biological analysis result is somewhat different from the respondents' perception that the pollution level in Situwangi is lower than that of Geredog and Nempel due to the dilution of water. However, it must be considered that the diversity of macro-zoobenthos in the different areas of the Cikawung river is influenced by water pollution and other factors, including temperature, sediments, and organic materials, etc. (cf. Putro 2014; Pamudji et al. 2015).

In general, however, the biological and chemical parameters (COD, BOD, and $\mathrm{pH}$ based on the government regulation 82, the year 2001) support the perception of village people of Karangwangi that the water of the Cikawung is in relatively good condition.
Table 2. Value of diversity index of macro-zoobenthos based on the Shannon-Wiener of Cikawung River,

\begin{tabular}{lc}
\hline Location & Diversity index of macro-zoobenthos \\
\hline Geredog & 1.05 \\
Nempel & 1.04 \\
Situwangi & 0.87 \\
\hline
\end{tabular}

Based on this study, it can be concluded that the village people of Karangwangi have exceptional local knowledge on aspects such as water categorization, pollution level, and pollution indicators of the Cikawung river. In addition, they are also aware that the quantity and quality of Cikawung river water have changed due to natural and anthropogenic factors.

\section{ACKNOWLEDGEMENTS}

This research was financially supported by the Academic Leadership Grant (ALG) program of Prof. Johan Iskandar. Therefore, we would like to express our special appreciation and thanks to Prof. Dr. Trihanggono Achmad, rector of Universitas Padjadjaran, for financial support and allowing us to undertake this research.

\section{REFERENCES}

Ahims-Putra HS. 1997. Water and Ciliwung water: a study on ethnoecology. Prisma 1 (26): 51-72, Jakarta. [Indonesian]

Aulia TOS, Arya HD.2010.Local Wisdom in Water Sources Management in Kuta Village. Sodality J Socio, Com Human Ecol 4 (3): 345-355.

Chaturvedi M, Sharma C, Chaturvedi M. Effects of Pesticides on Human Beings and Farm Animals: A Case Study. Res J Chem Environ Sci 1 (3): 14-19.

Hakim N, Murtilaksono K, Rusdiana. O. 2016. Land Utilization Conflict in Halimun Mountain National Forest. Sodality J Village Socio 4 (2): 128-138. DOI: 10.22500/sodality.v4i2.13377.

Halim F. 2014. Effect of Relationship Between Flood and Land Utilization Management in Manglayang Watershed. J Sci Eng 4 (1): 45-54. [Indonesian]

Indonesia Government Law No. 82 (2001). Management of Water Quality and Management of Water Pollution. Indonesian Ministry of Environment, Jakarta

Iskandar J, Budiawati SI. 2011. Sundanese Agroecosystem. PT Kiblat Buku Utama, Bandung. [Indonesian]

Iskandar J. 2009. Human Ecology and Sustainable Development. Magister of Environment Program, Padjadjaran University. Bandung. [Indonesian]

Iskandar J. 2012. Ethnobiology and Sustainable Development. AIPI, Bandung. [Indonesian]

Iskandar J. 2014. Human and Environment with All Alteration. Graha Ilmu. Yogyakarta. [Indonesian]

Juliana R. 2014. Differences in Plankton Comunity Structure in Segara Anak Swamp Structure Area, Cilacap [Hon. Thesis]. Jendral Soedirman University. Purwokerto. [Indonesian]

Kutanegara PM. 2014. Human, Environment, and River: Transformation of Social Life of Community of Code River Bank. Ombak Publisher, Yogyakarta. [Indonesian]

Lynch F, Hoelnsteiner RM, Cover CL. 1974. Data Gathering by Social Survey. Philippine Social Science Council. Quezon City.

Odum EP. 1971. Fundamental Ecology: Third Edition. UGM Press. Yogyakarta. [Indonesian] 
Pamuji A, Muskananfola MR, A'in C. 2015. Effect of Sediment Toward Macrozoobenthos Abundant in Bethawalang River Estuary. J Fish Sci Tech 10 (2): 129-135 [Indonesian]

Permana A. 2016. Number of Population, Geography, and Household of each Village in Cidaun. Local Government of Cianjur, Cianjur.

Putro SP. 2014. Macrozoobenthos Research Sampling Method and Application. Graha Ilmu. Yogyakarta

Reijntjes C, Haverkort B, Waters-Bayer A. 1992. Farming for the future: An introduction to Low-External-Input and Sustainable Agriculture. The MacMillan Press Ltd., London.

Rochgiyanti. 2011. River Function for People in Kuin Riverside, Banjarmasin City. Com J 5 (2): 229-237. [Indonesian]

Sari SW, Ruslan W, Bambang RW. 2014. Identification of Land of Sumbergunung Riverside Utilization in Batu City. Nat Source Environ J 1 (2): 25-30. [Indonesian]

Sillitoe P. 2002. Participant Observation to Participatory Development: Making Anthropology Work. In Sillitoe P, Bicker A, Pottier J (eds) Participating in Development: Approaches to Indigenous Knowledge. Routledge, London.

Sofia S, Fiqa AP. 2014. Kind of Plants Around Highland and Lowland Spring (Study Case in Malang City). LIPI. Pasuruan
Supriyono, E, Pong-Masak PR, Naiborhu PE. 2005. Study of Triclorofom Insecticide Toxicity Toward Oreochromis sp. Indonesian Aqua J 4 (2: 163-170. [Indonesian]. DOI: 10.19027/jai.4.163-171.

Susilo DA, Sarwoprasodjo S, Hubeis M, Ginting B. 2016. Discussion of Water Resources Management in Indonesia (Study Case 2002-2015). Sodality: Sodality J Village Socio 4 (3): 217-223.

Taufik I. 2011. Pesticide Pollution to Fishery in Sukabumi-West Java. Aquaculture Media 6 (1): 69-75. [Indonesian]. DOI: 10.15578/ma.6.1.2011.69-75.

Tilak KS, Veeraiah K, Raju JMP. 2007. Effects of Ammonia, Nitrite, and Nitrate on Hemoglobin Content and Oxygen Consumption of Freshwater Fish, Cyprinus carpio (Linnaeus). J Environ Biol 28 (1): 45-47.

Ulfah M, Rahayu P, Dewi LR. 2015. Local Plants' Morphology as A Potential Water Storage: Water conservation in Karangmanggis, Boja, Kendal, Central Java. Proceeding of National Conference of People Indonesian Biodiversitas 1 (3): 418-422. [Indonesian]

Wahid A. 2009. Analyzing Factors Influence Mamasa River Debit. SMARTek J 7 (3): 204-218.

Yuliana E, Adiwilaga M, Harris E, Pratiwi NTM. 2012. Relationship Between Phytoplankton Abundance and Physical-Chemical Parameters in Jakarta Bay. Akuatika 3 (2): 169-179. [Indonesian]. 